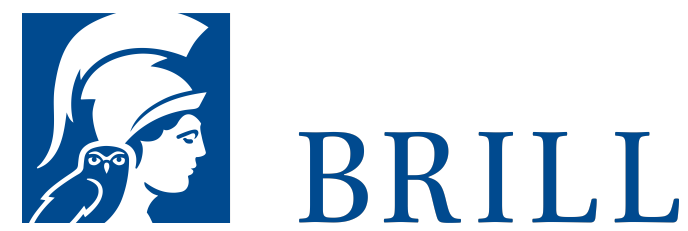

\title{
Armee und staatliche Integration: Preußen und die Habsburgermonarchie 1815-1866
}

Rekrutierungspolitik in den neuen Provinzen: Staatliches Handeln und Bevölkerung

Author: Bernhard Schmitt

Welche Rolle spielte das Integrationsinstrument Militär bei der Eingliederung neuer Provinzen in Preußen und in Österreich nach 1815 ? Der Band untersucht diese Frage, indem er die Einund Durchführung der Wehrpflicht in der preußischen Rheinprovinz und im habsburgischen Veneto analysiert und dabei sowohl staatliches Handeln wie auch die Reaktion der Bevölkerung betrachtet. Preußen und Österreich zielten seit 1815 darauf ab, die Bewohner ihrer neuen Provinzen am Rhein und in Oberitalien durch den Dienst im Militär zu guten Untertanen zu erziehen. Allerdings verharrte man in politischen Konzepten der Vorrevolutionszeit und trug mehr zu einer Regionalisierung des Staates als zu einer nationalen bzw. supranationalen Verschmelzung bei. Die Bevölkerung begegnete dem Militärdienst mit Gelassenheit. Obwohl sich die Konflikte mit den neuen Herren häuften, widersetzten sich die Menschen den Rekrutierungen nur in geringem Maße. Zwar wurde der Militärdienst nicht zu dem Katalysator nationaler Integration wie im Frankreich der Revolutions- und dem Preußen der Befreiungskriege, doch war er entgegen weitverbreiteter Ansichten keineswegs Anlass zum Widerstand gegen die preußischen bzw. österreichischen Herrscher am Rhein und in Oberitalien.

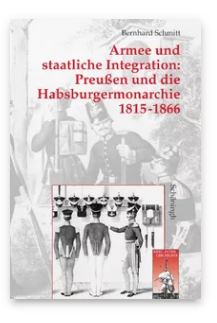

Pages: 332

Seiten

Language:

German

Subjects: Early

Modern History,

History

Publisher: Brill |

Schöningh

Series:

Krieg in der

Geschichte,

Volume: 36

Hardback

Publication date:

20 Mar 2007

ISBN: 978-3-

506-75626-8

List price

USD $\$ 71.00$ 
For more information see brill.com

Order information: Order online at brill.com +44330 333 0049 | customerservices@brill.com Submission information: brill.com/authors

Titles published by Brill | Fink, Brill | mentis or Brill | Schöningh: +49(o)715413279216| brill@brocom.de 